\title{
Heavy Metals in Fish Muscle from an Ethiopian Rift-Valley Lake (Hawassa) and a Neighboring Stream (Boicha): Assessment of Human Health Risks
}

\author{
${ }^{*}$ SAMUEL, B; ${ }^{1}$ SORSA, S; ${ }^{1}$ DANIEL, F; ${ }^{2}$ RIISE, G; ${ }^{1}$ ZINABU, GM \\ ${ }^{1}$ Department of Biology, College of Natural and Computational Sciences, Hawassa University, Hawassa, Ethiopia. \\ ${ }^{2}$ Faculty of Environmental Sciences and Natural Resource Management, Norwegian University of Life Sciences, As, Norway. \\ *Corresponding Author, Email: beksam10@gmail.com; Tel: +251913016302
}

\begin{abstract}
Concentrations of heavy metals (Cr, $\mathrm{Co}, \mathrm{Fe}, \mathrm{Ni}, \mathrm{Cu}, \mathrm{Zn}, \mathrm{As}, \mathrm{Se}, \mathrm{Pb}$ and $\mathrm{Hg}$ ) in muscle tissues of two fish species (Clarias gariepinus and Oreochromis niloticus) in an Ethiopian rift-valley lake (Hawassa) and a neighboring stream (Boicha) were determined. Target hazard quotients (THQ), hazard index (HI) and target cancer risk (TCR) were used as indices to evaluate potential human health risks from fish consumption. Average concentrations of metals decreased in the order $\mathrm{Zn}>\mathrm{Fe}>\mathrm{Se}>\mathrm{Cu}>\mathrm{Hg}>\mathrm{As}>\mathrm{Ni}>\mathrm{Cr}>\mathrm{Co}>\mathrm{Pb}$ and $\mathrm{Zn}>\mathrm{Fe}>\mathrm{Se}>\mathrm{Cu}>\mathrm{As}>\mathrm{Hg}>\mathrm{Cr}>\mathrm{Ni}>\mathrm{Pb}>\mathrm{Co}$ in muscle tissues of $C$. gariepinus and O. niloticus, respectively. Mean concentrations of $\mathrm{Hg}\left(0.34 \pm 0.04 \mathrm{mg} \mathrm{kg}^{-1}\right)$ in muscle tissues of $C$. gariepinus from Lake Hawassa, and As $(0.18 \pm 0.05$ $\left.\mathrm{mg} \mathrm{kg}^{-1}\right)$ as well as $\mathrm{Hg}\left(0.46 \pm 0.03 \mathrm{mg} \mathrm{kg}^{-1}\right)$ in muscle tissues of $C$. gariepinus from Boicha stream were above the safety limits set by WHO/FAO. Likewise, mean concentrations of As $\left(0.31 \pm 0.03 \mathrm{mg} \mathrm{kg}^{-1}\right)$ and $\mathrm{Hg}(0.19 \pm 0.05 \mathrm{mg}$ $\left.\mathrm{kg}^{-1}\right)$ in muscle tissues of $O$. niloticus from Lake Hawassa and $\mathrm{Cr}\left(0.19 \pm 0.03 \mathrm{mg} \mathrm{kg}^{-1}\right)$, As $\left(0.33 \pm 0.04 \mathrm{mg} \mathrm{kg}^{-1}\right)$, and $\mathrm{Hg}\left(0.34 \pm 0.09 \mathrm{mg} \mathrm{kg}^{-1}\right)$ in $O$. niloticus from Boicha stream were also above safety limits. From the results of human health risk assessments it was concluded that $\mathrm{Cr}, \mathrm{Cu}, \mathrm{Hg}$ and As pose potential health risks due to consumption of the two fish species from both water bodies. Moreover, effects of all heavy metals put together may affect human health as indicated by the high HI. Effluents from industries are assumed to be the main sources of the heavy metals. Therefore, regular monitoring of the water bodies and policy interventions with respect to waste disposal are recommended to protect the health of the ecosystem and the public.
\end{abstract}

\section{DOI: https://dx.doi.org/10.4314/jasem.v24i8.16}

Copyright: Copyright $(\mathbb{C} 2020$ Samuel et al. This is an open access article distributed under the Creative Commons Attribution License (CCL), which permits unrestricted use, distribution, and reproduction in any medium, provided the original work is properly cited.

Dates: Received: 30 May 2020; Revised: 03 July 2020; Accepted: 05August 2020

Keywords: Fish consumption, health risk, heavy metals, Lake Hawassa

Extended use of metals in industries has led to increased release of harmful heavy metals into the environment. Health risks due to the consumption of food items contaminated with heavy metals has increased globally especially in developing countries like Ethiopia (Berehanu et al., 2015). Heavy metals released from natural and anthropogenic sources pose serious threats to human and ecological health due to their toxicity, long persistence, bioaccumulation and biomagnifications in the food chain. Fish species that are at the top of aquatic food chain may concentrate large amounts of some heavy metals. Therefore, heavy metals bioaccumulate in fish tissues, and are finally transferred to other animals including man (Tariku et al., 2011; Ermias et al., 2014). This process may endanger public health through consumption of fish contaminated with metals. Fish makes up a large proportion of the human diet around Lakes and Rivers in Ethiopia (Alemayehu and Tamiru, 2019) as it is the most common source of animal protein, especially for families of poor fishers and fish vendors around Lake Hawassa. The Nile tilapia (Oreochromis niloticus) and
African catfish (Clarias gariepinus) are the two most common food fishes in the study area (FAO, 2014). Unfortunately, these fish are captured from water bodies where untreated or partially treated wastes from industries and urban centers are directly or indirectly discharged (Zinabu and Zerihun, 2002; Berehanu et $a l ., 2015)$. Information on the quantity of toxic micropollutants, like heavy metals, that discharge into the water bodies is critical to protect the ecosystem from pollution. Moreover, data on the levels of such pollutants in the biota, especially fish, of these water bodies is imperative with respect to public health. There are some studies on the concentrations of heavy metals in fish from Lake Hawassa and other Ethiopian water bodies (Amanial and Adugna, 2016; Dessie et al., 2019; Gure et al., 2019). However, the potential carcinogenic and non-carcinogenic health risks of heavy metals through fish consumption have not been studied in Ethiopia. Therefore, evaluation of health risks due to ingestion of heavy metals through fish consumption is extremely important in water bodies around Hawassa. The objectives of the current study 
were to determine the concentrations of heavy metals in muscle tissues of the two most common fish species: $C$. gariepinus and $O$. niloticus from Lake Hawassa and Boicha stream, and to estimate the human health risks from the consumption of these fish species.

\section{MATERIALS AND METHODS}

Description of the Study Area: Lake Hawassa formerly Lake Awassa - (Latitude: 633'-7³3' N; Longitude: $\left.38^{\circ} 22^{\prime}-38^{\circ} 29^{\prime}\right) \mathrm{E}$ is located near the city of Hawassa (Awassa), approximately $275 \mathrm{~km}$ South of Addis Ababa (the capital of Ethiopia), at an altitude of $1697-1742 \mathrm{~m}$ in the central Ethiopian rift valley (Yonas et al., 2018). The lake has a total area of 93 $\mathrm{km}^{2}$, mean depth of $12 \mathrm{~m}$ and maximum depth of $23 \mathrm{~m}$ (Yonas et al., 2018). Lake Hawassa is a freshwater lake in a closed basin with a catchment area of 1250 $\mathrm{km}^{2}$ (Yonas et al., 2018). In Hawassa, the main rainy season generally extends from June to October with a maximum mean annual rainfall of about $1150 \mathrm{~mm}$. The mean annual temperature of this area is $21.4^{\circ} \mathrm{C}$ with March and April having the highest $\left(31.5^{\circ} \mathrm{C}\right)$ and November and December having the lowest $\left(15^{\circ} \mathrm{C}\right)$ temperature (Gezahegn, 2017). Boicha stream is located in a wetland upstream at the North East side of Hawassa city in the vicinity of an Industrial Zone.

Sampling Sites: There were two sampling sites: Site 1 was the Lake Hawassa and Site 2 was Boicha stream, a direct receiver of effluents from different industries in the Hawassa Industrial Zone (Fig 1). Hawassa Industrial Zone has a cluster of factories including Textile, Moha-Soft Drink and BGI Brewery factories (Fig 1). All of these factories discharge their effluents into the nearby streams called Boga and Boicha that pass through the neighboring residential area before entering into"TikurWuha" -the only perennial river that flows into Lake Hawassa (Fig 1).

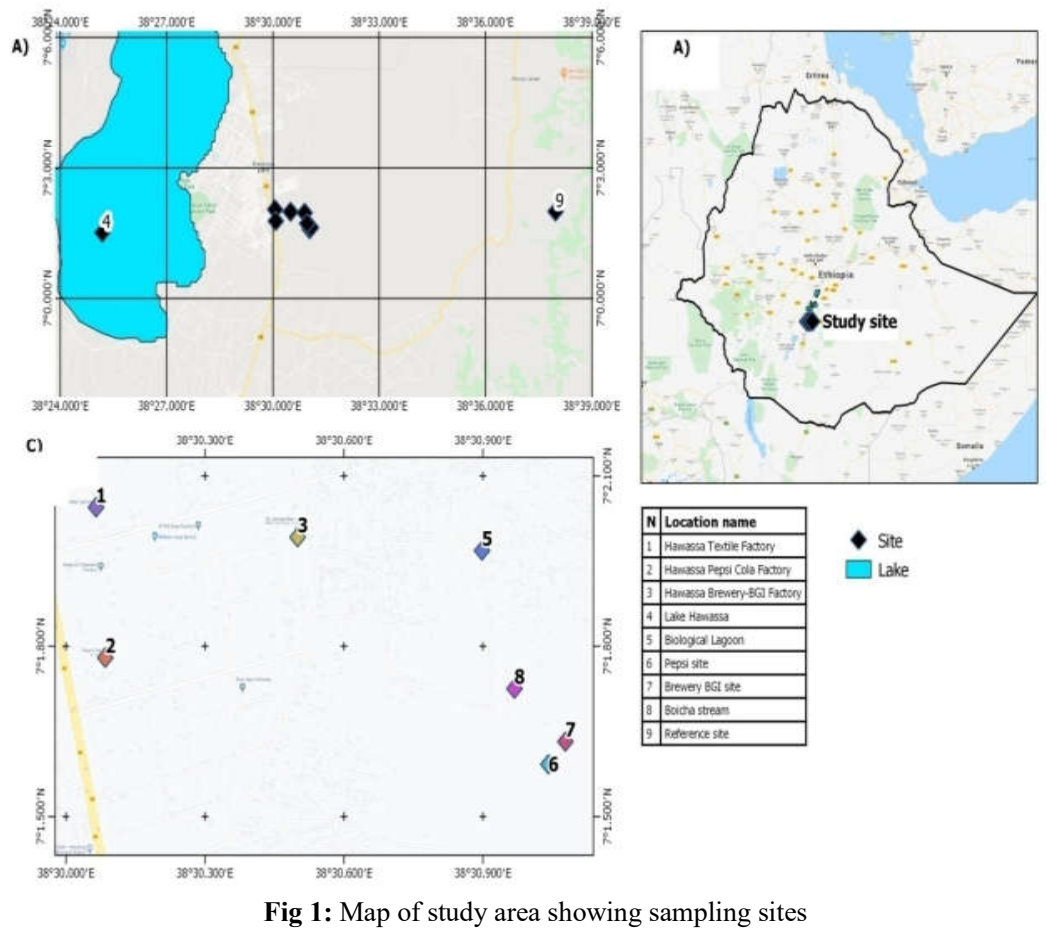

Sample Collection, Preparation and Analyses: Collection of Fish Samples: Fish sampling was done from Lake Hawassa and Boicha stream (Fig 1). Fourteen fish samples from each of C. gariepinus and O. niloticus were sampled from each sampling site in December 2020. Fish were purchased from fishermen who brought fresh catch of the two species of fish from Lake Hawassa and Boicha stream using their own nets. Before taking muscle tissue samples, each fish was washed with deionized water in order to remove possible adsorbed heavy metals on the skin or scale of the fish. Fish muscle sampling was done according to EMERGE protocol procedures (Rosseland et al., 2001). Fish were dissected to obtain muscle tissue using stainless-steel instruments (sterilized scissors, forceps and surgical blades). All laboratory equipments were cleaned with $70 \%$ concentrated $\mathrm{HNO}_{3}$ prior to sample preparation. Each muscle tissue sample was carefully covered with aluminum foil immediately after removal and was kept in a deep freezer at $-20^{\circ} \mathrm{C}$ for three days. Then, the frozen samples were air transported, in icebox filled with ice, 
to the Norwegian University of Life Sciences (NMBU) for heavy metal analyses.

Sample Preparation and Analyses for Heavy Metals: The samples were freeze dried at $-50^{\circ} \mathrm{C}$ and $180 \mathrm{mTorr}$ and mechanically crushed with pre-cleaned mortar and pestle, before they were stored in polyethylene bottles. Powdered samples were digested in a microwave digestion system as described by Alam et al. (2010). Powdered fish samples $(0.5 \mathrm{~g})$ were mixed with $6 \mathrm{ml}$ $65 \% \mathrm{HNO}_{3}$ and $2 \mathrm{ml} 30 \% \mathrm{H}_{2} \mathrm{O}_{2}$ (analytical grade chemicals, Merck, Germany). Muscle tissue samples were prepared following the EMERGE protocol procedures (Rosseland et al., 2001). After digestion and cooling, the samples were transferred to 20$\mathrm{ml}$ volumetric flasks and diluted to the mark with distilled water. The concentrations of heavy metals (Cr, $\mathrm{Co}, \mathrm{Fe}, \mathrm{Ni}, \mathrm{Cu}, \mathrm{Zn}, \mathrm{As}, \mathrm{Se}, \mathrm{Pb}$ and $\mathrm{Hg}$ ) were determined using Inductively Coupled Plasma Mass Spectrometry (Agilent 8800 ICP-MS).

Data Analyses: Data were analyzed using SPSS version 20. One way ANOVA was used to test whether the concentrations of heavy metals in fish muscle tissues vary depending on the site at $\alpha=0.05$ level of significance. Results were also compared with standard limits of FAO/WHO (1989 and 2011).

Potential Human Health Risk Assessment: The potential human health risk due to ingestion of heavy metals through the consumption of fish was assessed as non-carcinogenic and carcinogenic health risks.

Non-carcinogenic Health Risks: Target Hazard Quotient (THQ) and Hazard Index (HI) were used to estimate the potential non-carcinogenic health risks of heavy metals (USEPA, 2019). The THQ assesses health hazards for an individual heavy metal from fish consumption while HI assesses health hazards for combined heavy metals, and was estimated as the sum of individual metals THQ (USEPA, 2019). Target Hazard Quotient assumes a level of exposure below which it is unlikely for even sensitive population to experience adverse health effects (Kawser et al., 2016). The THQ and HI values were estimated using equation 1 and 2, respectively (USEPA, 2019). When the THQ and HI values are below 1.0 it means that the exposed population is safe in relation to the studied metal(s) or adverse non-carcinogenic health effects are unlikely to occur. If the THQ and HI values of metals are greater than 1.0, there are potential noncarcinogenic risks related to the heavy metal(s) analyzed (USEPA, 2019).

$\mathrm{THQ}=\frac{\text { EFxEDxFIRxC }}{\text { RFDxWABxTA }} \times 10^{-3}$
Where: THQ is target hazard quotient; EF is the exposure frequency - from 365 days/year for people who eat fish seven times a week to 52 days/year for people who eat fish once a week-according to the Food and Agriculture Organization (FAO, 2014). ED is the exposure duration equivalent to the average lifetime; average life expectancy in Ethiopia is 65 years according to the World Health Organization (WHO, 2015). FIR is the frequency of ingestion, i.e. average daily fish consumption rate (g/day/person), $\mathrm{C}$ is the concentration of the metal in the fish muscle $\left(\mathrm{mg} \mathrm{kg}^{-}\right.$ ${ }^{1}$ ), WAB is the average body weight $(\mathrm{kg})$, which was set by WHO (2012) to be $60 \mathrm{~kg}$ for adult Ethiopians. TA is the average exposure time for non-carcinogens (365 days/year $\mathrm{x} E D$ ), $10^{-3}$ is the unit conversion factor and RFD is the oral reference dose obtained from Integrated Risk Information System, Chemical Assessment Summary of United States Environmental Protection Agency (USEPA, 2003) database which was $0.003 \mathrm{mg} \mathrm{kg}^{-1} /$ day for $\mathrm{Cr}, 0.700(\mathrm{Fe}), 0.03(\mathrm{Co})$, $0.020(\mathrm{Ni}), 0.040(\mathrm{Cu}), 0.300$ (Zn), 0.0003 (As), 0.005 (Se), $0.0001(\mathrm{Hg})$ and 0.0035 for $\mathrm{Pb}$.

Although Ethiopians are traditionally meat eaters, eating habits have lately been shifting in favor of fish in areas and communities where there is regular and sufficient fish supply (Yared et. al., 2013). In such communities, annual fish consumption can exceed 10 $\mathrm{kg} /$ person (FAO, 2014). Thus, the daily average fish consumption rate (DR) was estimated at $30 \mathrm{~g} \mathrm{~d}^{-1}$ per person (Yared et. al., 2013).

$\mathrm{HI}=\sum \mathrm{THQ}$

The THQ and HI were calculated for the people, who eat fish one to seven days a week from Lake Hawassa and Boicha stream.

Target Cancer Risks (TCRs): Target cancer risks (TCR) were estimated as the incremental probability of an individual to develop cancer over a lifetime exposure to that potential carcinogen (USEPA, 1989). Acceptable risk levels for carcinogens range from $10^{-}$ ${ }^{4}$ (risk of developing cancer over a human lifetime is 1 in 10,000 ) to $10^{-6}$ (risk of developing cancer over a human lifetime is 1 in $1,000,000)$. The equation used for estimating the TCR is as follows:

$\mathrm{TCR}=\frac{\text { EFxEDxCxCSFO }}{\text { WABxTA }} \times 10^{-3}$

Where: TCR is target cancer risk (lifetime cancer risk); $\mathrm{C}$ is the concentration of the metal in the fish muscle $\left(\mathrm{mg} \mathrm{kg}^{-1}\right)$; CSFO is the oral carcinogenic slope factor from integrated risk information system database (USEPA, 2010) which was $1.5 \mathrm{mg} \mathrm{kg}^{-1} /$ day 
for As, $1.7(\mathrm{Ni}), 0.5(\mathrm{Cr})$ and $0.0085 \mathrm{mg} \mathrm{kg}^{-1} /$ day for $\mathrm{Pb}$. The TCR was estimated for $\mathrm{Cr}, \mathrm{Ni}, \mathrm{As}$ and $\mathrm{Pb}$ only since these elements may promote both noncarcinogenic and carcinogenic effects depending on the exposure dose. According to the International Agency for Research on Cancer (USEPA, 2012), As, $\mathrm{Cd}$ and $\mathrm{Ni}$ are known as Group $\mathrm{A}$ and $\mathrm{Pb}$ is known as Group B carcinogens.

\section{RESULTS AND DISCUSSIONS}

Concentrations of Heavy Metals in Fish Muscle: Concentrations of heavy metals in the muscle tissues of $C$. gariepinus and $O$. niloticus are presented in Table 1. Mean concentrations of heavy metals generally followed the order: $\mathrm{Zn}>\mathrm{Fe}>\mathrm{Se}>\mathrm{Cu}>\mathrm{Hg}>\mathrm{As}>\mathrm{Ni}>\mathrm{Cr}>\mathrm{Pb}>\mathrm{Co}$ and $\mathrm{Zn}>\mathrm{Fe}>\mathrm{Se}>\mathrm{Cu}>\mathrm{As}>\mathrm{Hg}>\mathrm{Cr}>\mathrm{Ni}>\mathrm{Pb}>\mathrm{Co}$ in the muscle tissues of $C$. gariepinus and $O$. niloticus, respectively. The maximum mean concentration of heavy metal obtained in muscle tissues of $C$. gariepinus was for $\mathrm{Zn}$ $\left(22.79 \pm 1.19 \mathrm{mg} \mathrm{kg}^{-1}\right)$ from Boicha stream and the minimum value was for $\mathrm{Pb}\left(0.05 \pm 0.002 \mathrm{mg} \mathrm{kg}^{-1}\right)$ from Lake Hawassa. Similarly, the maximum mean concentration in muscle tissues of $O$. niloticus was for $\mathrm{Zn}\left(22.64 \pm 4.45 \mathrm{mg} \mathrm{kg}^{-1}\right)$ from Boicha stream and the minimum value was for $\mathrm{Pb}\left(0.01 \pm 0.001 \mathrm{mg} \mathrm{kg}^{-1}\right)$ from Lake Hawassa.

The fact that the mean concentrations of all the heavy metals, except $\mathrm{Ni}$ and $\mathrm{Co}$, investigated in this study were higher in the muscle tissues of both fish species sampled from Boicha stream than in those from Lake Hawassa could be attributed to the effluents from industries and urban wastes that the stream receives. This is very likely, given that the effluents may contain some heavy metals as they are not treated at all or the treatments were inadequate when there was some kind of treatment. Studies on the metal concentrations of the effluents have shown that they contained heavy metals like $\mathrm{Cr}, \mathrm{Co}, \mathrm{Cu}, \mathrm{As}, \mathrm{Cd}, \mathrm{Hg}, \mathrm{Ni}, \mathrm{Se}, \mathrm{Pb}, \mathrm{Fe}$ and etc. in effluents (Zinabu and Zerihun, 2002; Berehanu et al., 2015). The reasons why the concentrations of the metals were lower in Lake Hawassa than the Boicha stream could be a dilution effect and $\backslash$ or removal of the heavy metals in route. Boicha stream flows through the Shallo wetland and it is possible that some of the heavy metals could be removed by aquatic plants (macrophytes) on the way to the lake.

Earlier studies have shown different concentrations of $\mathrm{Cr}$ in the two species of fish we have analyzed in this study. Larissa et al. (2013) reported mean concentrations of 0.29 and $0.7 \mathrm{mg} \mathrm{kg}^{-1}$ of $\mathrm{Cr}$ in muscle tissues of $C$. gariepinus from Lake Hawassa and Koka reservoir, respectively. These values are much higher than the values 0.08 and $0.09 \mathrm{mg} \mathrm{kg}^{-1}$ from Lake
Hawassa and Boicha stream, respectively obtained in this study. Other reports from studies made on fish in some other Ethiopian water bodies have also shown higher concentrations of $\mathrm{Cr}$ in $\mathrm{O}$. niloticus. The study of Gure et al. (2019) revealed a much higher concentration of $\mathrm{Cr}\left(10.31 \mathrm{mg} \mathrm{kg}^{-1}\right)$ in the same fish from Gilgel Gibe (I) Hydroelectric Dam Reservoir, Ethiopia. The differences could be attributed to variances in sample handling, including the methods used, and season of sampling. Chromium has the ability to be rapidly eliminated from the body of fish and does not normally accumulate in fish and hence low concentrations were reported even from industrialized parts of the world (Mahboob et al., 2014). Therefore, the low concentrations of $\mathrm{Cr}$ in the muscle tissues of the fish in the present study might not necessarily signify the $\mathrm{Cr}$ pollution level of the water body from which the fish were caught.

The result of the present study revealed that the concentration of $\mathrm{Fe}$ in the muscle tissue of $O$. niloticus was lower than the values reported by Abayneh et al. (2003) Fe (29.04 mg kg-1) from Lake Hawassa, Ethiopia. Again we attribute the difference to sample handling, instruments used and the methods employed for the analyses - although temporal changes in the ecosystem during such a long time (nearly two decades) cannot be discounted. Other researchers also reported higher values of Fe concentrations in muscle tissues of the same fish species from different water bodies. For instance: Amanial and Adugna (2016) reported mean $\mathrm{Fe}$ concentrations of $18.98 \mathrm{mg} \mathrm{kg}^{-1}$ from Lake Chamo, Ethiopia. The fact that mean Fe concentration in the muscle tissues of $O$. niloticus was lower in the present study compared to studies from other Ethiopian freshwater bodies could be due to the absence of iron and steel industries in the catchment area of the present study (Hawassa Industrial Zone) where only factories like textile, soft drink, brewery, detergent, etc. exist.

Yared et al. (2013) reported a much lower, compared to the present study, mean concentration of Co: 0.005 $\mathrm{mg} \mathrm{kg}^{-1}$ and $0.006 \mathrm{mg} \mathrm{kg}^{-1}$, in muscle tissues of $C$. gariepinus and $O$. niloticus, respectively from Lake Hawassa. The higher Co concentrations in the muscle tissues of the fish in the present study might be due to the discharge of effluents from the textile factory, which contains Co contaminants, into the lake and the stream. Zinabu and Zerihun (2002) have reported mean Co concentration of $0.28 \mu \mathrm{g} \mathrm{L}^{-1}$ in effluents from Hawassa textile factory. Earlier studies have shown different concentrations of $\mathrm{Cu}$ in the two species of fish we have analyzed in this study. Abayneh et al. (2003) reported mean concentrations of $1.53 \mathrm{mg} \mathrm{kg}^{-1}$ of $\mathrm{Cu}$ in muscle tissues of $C$. gariepinus from Lake 
Hawassa and Dessie et al. (2019) reported concentrations of $10.7 \mathrm{mg} \mathrm{kg}^{-1}$ of $\mathrm{Cu}$ in muscle tissues of $O$. niloticus from Lake Hayq, Ethiopia. These values are much higher than the values $(0.76$ and 1.13 $\mathrm{mg} \mathrm{kg}{ }^{-1}$ in muscle tissues of $C$. gariepinus and $O$. niloticus, respectively) obtained in this study. From a study in Lake Chomo, Ethiopia, Amanial and Adugna (2016) reported 2.86 and $1.68 \mathrm{mg} \mathrm{kg}^{-1}$ of $\mathrm{Zn}$ in muscle tissues of $C$. gariepinus and $O$. niloticus, respectively. Both of these values are much lower than the mean concentrations detected in the muscle tissues of the fish (22.71 and $17.93 \mathrm{mg} \mathrm{kg}^{-1}$ in muscle tissues of $C$. gariepinus and $O$. niloticus, respectively) in this study. Reasons for such differences are not straight forward to explain except for assumed methodological differences.

Larissa et al. (2013), from a study in Lake Hawassa, reported 0.07 and $0.05 \mathrm{mg} \mathrm{kg}^{-1}$ of As in muscle tissues of $C$. gariepinus and $O$. niloticus, respectively. Both of these values were lower than the mean concentrations detected in the muscle tissues of the fish $\left(0.14\right.$ and $0.32 \mathrm{mg} \mathrm{kg}^{-1}$ in muscle tissues of $C$. gariepinus and $O$. niloticus, respectively) in this study. The high concentration of As in the muscle tissue of both fish species in the present study may probably be due to effluents discharged into Lake Hawassa and Boicha stream from factories (like: textile and ceramics) in the industrial zone that are likely to contain high As concentration (Zinabu and Zerihun, 2002). According to Zinabu and Zerihun (2002), effluents from Hawassa textile factory contained high concentration of As $\left(10.6 \mu \mathrm{g} \mathrm{L}^{-1}\right)$. Moreover, there are many hot springs around Hawassa that contain high concentrations of As (Zinabu et al., 2004). The water from these hot springs, which ends up in Lake Hawassa, is one likely source of the high As in muscle tissues of the fish. Additionally, the higher mean As concentration in fish from Boicha stream may be due to the long term usage of As containing pesticides by farmers in the watershed.

The higher levels of Se in fish from Lake Hawassa may be associated with industrial discharges, as well as aerial deposition and agricultural use of pesticides and phosphate fertilizers in the watershed of the lake. Zinabu and Zerihun (2002) reported $5.44 \mu \mathrm{g} \mathrm{L}^{-1}$ of Se in effluents discharged from the Hawassa textile factory. Furthermore, hot springs in the surroundings of Lake Hawassa were reported to contain high concentrations of Se (Zinabu et al., 2004). It is, therefore, possible to assume that the high $\mathrm{Se}$ concentrations in the fish are related to the human activity and other natural causes in the vicinity of the lake. On the other hand, there are reports of much lower values of $\mathrm{Se}$ in muscle tissues of $C$. gariepinus
(0.001 $\left.\mathrm{mg} \mathrm{kg}^{-1}\right)$ and O. niloticus $\left(0.0008 \mathrm{mg} \mathrm{kg}^{-1}\right)$ from Lake Hawassa (Larissa et al., 2013). Again, these differences may not necessarily indicate actual but methodological differences.

The mean concentration of $\mathrm{Hg}$ in muscle tissues of $C$. gariepinus in this study was higher than the values in fish of the same species reported from two other lakes in Ethiopia. Tariku et al. (2011) and Ermias et al. (2014) reported 0.003 and $0.06 \mathrm{mg} \mathrm{kg}^{-1}$ of $\mathrm{Hg}$, respectively from Lake Ziway. Larissa et al. (2013) and Ermias et al. (2014) reported $0.27 \mathrm{mg} \mathrm{kg}^{-1}$ and $0.14 \mathrm{mg} \mathrm{kg}^{-1}$ of $\mathrm{Hg}$, respectively from Koka Reservoir. Likewise, the result of the present study showed that the level of $\mathrm{Hg}$ in muscle tissues of $O$. niloticus was higher than values reported by other workers from Lakes Hawassa and Ziway. Tariku et al.(2011) and Ermias et al. (2014) reported 0.001 and $0.01 \mathrm{mg} \mathrm{kg}^{-1}$ of $\mathrm{Hg}$, respectively from Lake Ziway whereas Larissa et al. (2013) reported $0.12 \mathrm{mg} \mathrm{kg}^{-1}$ from Lake Hawassa.

The high concentration of $\mathrm{Hg}$ in the muscle tissues of the fish in the present study might again be due to effluents from factories in the industrial zone (Zinabu and Zerihun, 2002) and the water from hot springs (Zinabu et al., 2004) that flow into Lake Hawassa (see the discussion for As). Zinabu and Zerihun (2002) reported high concentration of $\mathrm{Hg}\left(3.8 \mu \mathrm{g} \mathrm{L}^{-1}\right)$ in effluents from Hawassa textile factory that might have contaminated the neighboring water bodies.

The present study showed that the concentrations of $\mathrm{Pb}$ in muscle tissues of $O$. niloticus $(0.014$ and 0.015 $\mathrm{mg} \mathrm{kg}{ }^{-1}$ from Lake Hawassa and Boicha stream, respectively) from both sampling sites were lower than those reported by several researchers from different water bodies in Ethiopia. For instance: Dessie et al. (2019) and Gure et al. (2019) reported 2.10 and 8.39 $\mathrm{mg} \mathrm{kg}^{-1}$ from Lake Hayq and Gilgel Gibe (I) Hydroelectric Dam Reservoir, respectively. Although the concentrations of $\mathrm{Pb}$ in muscle tissues of the fish in the present study are lower than those reported by other workers, they still indicate that there is some degree of pollution possibly from industrial and municipal effluents discharged into the water bodies (Zinabu and Zerihun, 2002).

There were statistically significant $(P<0.05)$ site dependent differences in the mean concentrations of all heavy metals except four ( $\mathrm{Cr}, \mathrm{Co}, \mathrm{Zn}$ and $\mathrm{Se})$ in the muscle tissues of $C$. gariepinus. Similarly, there were statistically significant differences $(P<0.05)$ in the mean concentrations of all heavy metals except four $(\mathrm{Fe}, \mathrm{As}, \mathrm{Se}$ and $\mathrm{Pb})$ in the muscle tissues of $O$. niloticus among the sampling sites (Table 1). This suggests that 
there were differences in heavy metal pollution levels between the lake and the stream.

The mean concentration of $\mathrm{Cr}$ in muscle tissues of $O$. niloticus from Boicha stream is above the MPL in the diet of humans according to the FAO/WHO (1989) standard (Table 1). This shows that $O$. niloticus from Boicha stream may not be safe for human consumption with regard to $\mathrm{Cr}$ toxicity. Similarly, the mean As concentrations in muscle tissues of $C$. gariepinus from Boicha stream and mean As concentrations in the muscle tissues of $O$. niloticus from both sites are above the MPL in the diet of humans according to FAO/WHO (2011) (Table 1). This shows that $C$. gariepinus from Boicha stream and
O. niloticus from both sampling sites are unsafe for human consumption with regard to As toxicity. Longterm exposure of humans to As may cause several health problems including skin lesions (hyperkeratosis and pigmentation changes), blackfoot disease, circulatory disorders, diabetes, and cancers of the bladder, lung, kidney, and liver (Gbaruko et al., 2010). Likewise, the mean $\mathrm{Hg}$ concentrations in muscle tissues of $C$. gariepinus and $O$. niloticus from both sampling sites are above the MPL in the diet of humans according to FAO/WHO (2011) standards (Table 1). Therefore, the two fish species from Lake Hawassa and Boicha stream could be unsafe for human consumption with respect to $\mathrm{Hg}$ toxicity.

Table 1 Heavy metal concentrations $\left(\mathrm{mg} \mathrm{kg}^{-1}\right.$, dry weight) in fish muscle from Lake Hawassa and Boicha stream $(\mathrm{Mean} \pm \mathrm{SD}, \mathrm{n}=14)$.

\begin{tabular}{|c|c|c|c|c|c|c|c|}
\hline \multirow[b]{3}{*}{ Fish species } & \multirow{3}{*}{$\begin{array}{l}\text { Heavy } \\
\text { metals }\end{array}$} & \multicolumn{4}{|c|}{ Site } & \multirow{3}{*}{ MPL } & \multirow{3}{*}{ Reference } \\
\hline & & \multicolumn{2}{|c|}{ Lake Hawassa } & \multicolumn{2}{|c|}{ Boicha stream } & & \\
\hline & & Mean & $\mathrm{SD}$ & Mean & SD & & \\
\hline Clarias & $\mathrm{Cr}$ & $0.08^{\mathrm{a}}$ & 0.02 & $0.09^{\mathrm{a}}$ & 0.01 & 0.15 & FAO/WHO, 1989 \\
\hline \multirow{9}{*}{ gariepinus } & $\mathrm{Fe}$ & $11.28^{\mathrm{a}}$ & 2.54 & $27.14^{\mathrm{b}}$ & 3.90 & 100 & FAO/WHO, 2011 \\
\hline & $\mathrm{Co}$ & $0.06^{\mathrm{a}}$ & 0.002 & $0.06^{\mathrm{a}}$ & 0.001 & -- & ----- \\
\hline & $\mathrm{Ni}$ & $0.10^{\mathrm{a}}$ & 0.01 & $0.08^{\mathrm{b}}$ & 0.01 & 0.15 & FAO/WHO, 1989 \\
\hline & $\mathrm{Cu}$ & $0.62^{\mathrm{a}}$ & 0.08 & $0.89^{\mathrm{b}}$ & 0.16 & 3.0 & FAO/WHO, 1989 \\
\hline & $\mathrm{Zn}$ & $22.64^{\mathrm{a}}$ & 4.45 & $22.79^{\mathrm{a}}$ & 1.19 & 40.0 & FAO/WHO, 1989 \\
\hline & As & $0.10^{\mathrm{a}}$ & 0.003 & $0.18^{b}$ & 0.05 & 0.1 & $\mathrm{FAO} / \mathrm{WHO}, 2011$ \\
\hline & $\mathrm{Se}$ & $2.08^{\mathrm{a}}$ & 1.06 & $2.61^{\mathrm{a}}$ & 0.28 & ---- & 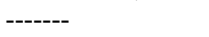 \\
\hline & $\mathrm{Hg}$ & $0.34^{a}$ & 0.04 & $0.46^{b}$ & 0.03 & 0.06 & FAO/WHO, 2011 \\
\hline & $\mathrm{Pb}$ & $0.05^{\mathrm{a}}$ & 0.002 & $0.06^{\mathrm{b}}$ & 0.004 & 1.0 & FAO/WHO, 2011 \\
\hline Oreochromis & $\mathrm{Cr}$ & $0.14^{\mathrm{a}}$ & 0.01 & $0.19^{b}$ & 0.03 & 0.15 & FAO/WHO, 1989 \\
\hline \multirow[t]{9}{*}{ Niloticus } & $\mathrm{Fe}$ & $9.45^{\mathrm{a}}$ & 2.81 & $11.34^{\mathrm{a}}$ & 2.18 & 100 & FAO/WHO, 2011 \\
\hline & $\mathrm{Co}$ & $0.01^{\mathrm{a}}$ & 0.001 & $0.02^{\mathrm{b}}$ & 0.002 & ---- & 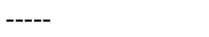 \\
\hline & $\mathrm{Ni}$ & $0.09^{\mathrm{a}}$ & 0.02 & $0.05^{\mathrm{b}}$ & 0.01 & 0.15 & FAO/WHO, 1989 \\
\hline & $\mathrm{Cu}$ & $0.92^{\mathrm{a}}$ & 0.18 & $1.33^{\mathrm{b}}$ & 0.44 & 3.0 & FAO/WHO, 1989 \\
\hline & $\mathrm{Zn}$ & $16.50^{\mathrm{a}}$ & 1.87 & $19.36^{\mathrm{b}}$ & 2.56 & 40.0 & FAO/WHO, 1989 \\
\hline & As & $0.31^{\mathrm{a}}$ & 0.03 & $0.33^{\mathrm{a}}$ & 0.04 & 0.1 & FAO/WHO, 2011 \\
\hline & $\mathrm{Se}$ & $1.34^{\mathrm{a}}$ & 0.55 & $1.43^{\mathrm{a}}$ & 0.14 & ---- & ----- \\
\hline & $\mathrm{Hg}$ & $0.19^{\mathrm{a}}$ & 0.05 & $0.34^{b}$ & 0.09 & 0.06 & FAO/WHO, 2011 \\
\hline & $\mathrm{Pb}$ & $0.014^{\mathrm{a}}$ & 0.001 & $0.015^{\mathrm{a}}$ & 0.001 & 1.0 & FAO/WHO, 2011 \\
\hline
\end{tabular}

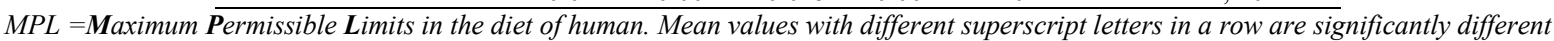
from each other $(\alpha=0.05)$. Values in bold are those above the MPL in the diet of humans according to the standards included in this table.

Differences in the Concentrations of Heavy Metals among the Two Fish Species: The mean concentrations of heavy metals in the muscle tissues of the two fish species from the two water bodies $($ Mean \pm SD) are presented in Table 2. As depicted in this table, there were statistically significant $(P<0.05)$ differences in the mean concentrations of all the metals among the muscle tissues of $C$. gariepinus and O. niloticus. Accordingly, the mean concentrations of $\mathrm{Cr}\left(0.163 \pm 0.032 \mathrm{mg} \mathrm{kg}^{-1}\right), \mathrm{Cu}\left(1.123 \pm 0.393 \mathrm{mg} \mathrm{kg}^{-}\right.$ $\left.{ }^{1}\right)$ and As $\left(0.321 \pm 0.031 \mathrm{mg} \mathrm{kg}^{-1}\right)$ in muscle tissues of $O$. niloticus were higher than the concentrations in $C$. gariepinus. In the same way, the mean concentrations of Fe $\left(19.211+1.644 \mathrm{mg} \mathrm{kg}^{-1}\right), \mathrm{Co}(0.059+0.003 \mathrm{mg}$ $\left.\mathrm{kg}^{-1}\right)$, Ni $\left(0.091 \pm 0.016 \mathrm{mg} \mathrm{kg}^{-1}\right), \mathrm{Zn}(22.714 \pm 3.196$ $\left.\mathrm{mg} \mathrm{kg}^{-1}\right), \mathrm{Se}\left(2.35 \pm 0.811 \mathrm{mg} \mathrm{kg}^{-1}\right), \mathrm{Hg}(0.399 \pm 0.068$ $\left.\mathrm{mg} \mathrm{kg}^{-1}\right)$ and $\mathrm{Pb}\left(0.055 \pm 0.003 \mathrm{mg} \mathrm{kg}^{-1}\right)$ were higher in muscle tissues of $C$. gariepinus compared to their concentrations in $O$. niloticus.

Table 2 Concentrations of heavy metals $\left(\mathrm{mg} \mathrm{kg}^{-1}\right)$ in fish species from both sampling sites (Mean $+\mathrm{SD}, \mathrm{n}=28$ ) depicting the differences in the levels of the heavy metals among the two species of fish.

\begin{tabular}{lll}
\hline & \multicolumn{2}{c}{ Fish species } \\
\cline { 2 - 3 } Heavy & Clarias & $\begin{array}{l}\text { Oreochromis } \\
\text { miloticus }\end{array}$ \\
\hline $\mathrm{Cr}$ & $0.081 \pm 0.016^{\mathrm{a}}$ & $0.163 \pm 0.032^{\circ}$ \\
$\mathrm{Fe}$ & $19.211 \pm 1.644^{\mathrm{a}}$ & $10.396 \pm 2.65^{\mathrm{b}}$ \\
$\mathrm{Co}$ & $0.059 \pm 0.003^{\mathrm{a}}$ & $0.013 \pm 0.004^{\mathrm{b}}$ \\
$\mathrm{Ni}$ & $0.091 \pm 0.016^{\mathrm{a}}$ & $0.072 \pm 0.026^{b}$ \\
$\mathrm{Cu}$ & $0.756 \pm 0.191^{\mathrm{b}}$ & $1.13 \pm 0.393^{\mathrm{b}}$ \\
$\mathrm{Zn}$ & $22.714 \pm 3.195^{\mathrm{a}}$ & $17.929 \pm 2.638^{\mathrm{b}}$ \\
$\mathrm{As}$ & $0.14 \pm 0.054^{\circ}$ & $0.321 \pm 0.032^{\mathrm{b}}$ \\
$\mathrm{Se}$ & $2.35 \pm 0.811^{\mathrm{a}}$ & $1.379 \pm 0.147^{b}$ \\
$\mathrm{Hg}$ & $0.399 \pm 0.068^{\mathrm{b}}$ & $0.261 \pm 0.019^{b}$ \\
$\mathrm{Bb}$ & $0.055 \pm 0.004^{\mathrm{b}}$ & $0.014 \pm 0.002^{\mathrm{b}}$ \\
\hline
\end{tabular}

Mean values with different superscript letters in a row are significantly different from each other $(\alpha=0.05)$. 
These differences in the concentrations of heavy metals among the two fish species might be due to the differences in habitat use, feeding habits of the fish, growth dilution, and chemical behavior of the metals. Tariku et al. (2011) pointed out that $\mathrm{Hg}$ in fishes showed considerably higher concentrations at high trophic levels indicating trophic transfer and bioaccumulation of $\mathrm{Hg}$.

Health Risks Associated with Fish Consumption: Target Hazard Quotient (THQ): The results of THQ through consumption of $C$. gariepinus and $O$. niloticus from Lake Hawassa and Boicha stream for people who eat these fish species one to seven times a week are shown in Table 3 . The THQ values for heavy metals from consumption of $C$. gariepinus followed the order: $\mathrm{Hg}>\mathrm{Se}>\mathrm{As}>\mathrm{Zn}>\mathrm{Fe}>\mathrm{Cr}>\mathrm{Cu}>\mathrm{Pb}>\mathrm{Ni}>\mathrm{Co}$ and the order of values from consumption of $O$. niloticus was $\mathrm{Hg}>\mathrm{As}>\mathrm{Se}>\mathrm{Zn}>\mathrm{Cr}>\mathrm{Pb}>\mathrm{Cu}>\mathrm{Fe}>\mathrm{Ni}>\mathrm{Co}$. Ranges of THQ values from consumption of $C$. gariepinus from Boicha stream for the heavy metals were: $\mathrm{Cr}(0.002-$ $0.017)$, Fe (0.003-0.023), $\mathrm{Cu}$ (0.002-0.014), As (0.052-0.362), Se (0.045-0.314) and $\mathrm{Hg}(0.389$ 2.730). In the same way, THQ values from consumption $O$. niloticus from Boicha stream ranged from 0.004-0.037 for $\mathrm{Cr}, 0.002-0.010(\mathrm{Fe})$, 0.003 $0.020(\mathrm{Cu}), 0.006-0.039(\mathrm{Zn}), 0.094-0.662$ (As) 0.024$0.172(\mathrm{Se}), 0.287-2.016(\mathrm{Hg})$ and $0.004-0.026(\mathrm{~Pb})$. These ranges of values were higher in both fish species from Boicha stream than those from Lake Hawassa (Table 3). The results of this study show that there is a higher probability of non-carcinogenic health risks from ingestion of $\mathrm{Cr}, \mathrm{Fe}, \mathrm{Cu}, \mathrm{As}, \mathrm{Se}$ and $\mathrm{Hg}$ individually through the consumption of $C$. gariepinus from Boicha stream compared to consumption of the same fish species from Lake Hawassa. The underlying reason is that the THQ values for $\mathrm{Cr}, \mathrm{Fe}, \mathrm{Cu}, \mathrm{As}$, Se and $\mathrm{Hg}$ through consumption of $\mathrm{C}$. gariepinus from Boicha stream were higher than those from Lake Hawassa. Likewise, there is a higher probability of non-carcinogenic health risks from ingestion of $\mathrm{Cr}, \mathrm{Fe}$, $\mathrm{Cu}, \mathrm{Zn}, \mathrm{As}, \mathrm{Se}, \mathrm{Hg}$ and $\mathrm{Pb}$ individually through the consumption of $O$. niloticus from Boicha stream compared to consumption of the same fish species from Lake Hawassa at all levels of exposure. This is probably due to a high level of heavy metal pollution in Boicha stream than in the Lake Hawassa. This is very possible given that the stream directly receives effluents from the industrial zone where Hawassa Textile, Moha Soft Drink and Brewery-BGI factories are operating. Abdulali et al. (2013) from their study in Langat River, Malaysia, reported higher THQ ranges for $\mathrm{Ni}(0.06-0.31)$ and $\mathrm{Pb}(0.05-0.23)$ than our findings. However, they reported lower THQ ranges for $\mathrm{Cu}$ (0.01-0.05) and $\mathrm{Zn}$ (0.02-0.12) through consumption of $O$. niloticus one to five days a week.
The statistically significant differences $(P<0.05)$ in THQ values for $\mathrm{Cr}, \mathrm{Fe}, \mathrm{Cu}$, As, $\mathrm{Se}$ and $\mathrm{Hg}$ through the consumption of $C$. gariepinus and $O$. niloticus among the study sites, imply that there were different contamination levels for the fishes between the sites. The fact that the THQ values for all heavy metals, except $\mathrm{Hg}$, through consumption of $C$. gariepinus and $O$. niloticus from both study sites were less than unity is an indication that there is potentially little noncarcinogenic health risks from ingestion of $\mathrm{Cr}, \mathrm{Fe}, \mathrm{Co}$, $\mathrm{Ni}, \mathrm{Cu}, \mathrm{Zn}, \mathrm{As}$, Se and $\mathrm{Pb}$ individually through consumption of the two species of fish from both sites. The THQ values for $\mathrm{Hg}$ through consumption of $C$. gariepinus from both sampling sites were greater than unity; therefore, there are potential non-carcinogenic health risks from ingestion of $\mathrm{Hg}$ through consumption of this fish species three or more days a week from Boicha stream, and five or more days a week from Lake Hawassa. Likewise, the THQ values for $\mathrm{Hg}$ through consumption of $O$. niloticus from both sampling sites were above the safe limit-greater than 1. Therefore, there are potential non-carcinogenic health risks from ingestion of $\mathrm{Hg}$ through consumption of this fish species five or more days a week from Boicha stream, and every day from Lake Hawassa. These health risks cannot be undermined as organic form of $\mathrm{Hg}$ (Methylmercury) is a potent neurotoxic chemical. Mercury is known to cause permanent damage to the brain and the central nervous system as well as heart, kidney and lung diseases (Honda et al., 2006). Unborn children are the most vulnerable group - the exposure being mainly from fish in the diet of the mother (WHO, 2007). The families of fishers and fish food vendors around the study areas are probably victims of $\mathrm{Hg}$ intoxication through fish consumption.

Differences in THQ Values of Heavy Metals Among the Two Fish Species: Among heavy metals examined in this study, the highest THQ values were obtained for $\mathrm{Hg}$ from the consumption of both fish species from the two sampling sites at all levels of exposure followed by As and Se. This indicates that these three heavy metals ( $\mathrm{Hg}$, As and $\mathrm{Se}$ ) have the highest potential non-carcinogenic health risks from the consumption of the two species of fish from both sites. The highest THQ values for $\mathrm{Hg}$, As and $\mathrm{Se}$ in the muscle tissues of the two fish species from both sampling sites could be due to industrial effluents as well as the presence of hot springs around the study areas (Zinabu et al., 2004). These metals (Hg, As and Se) can adversely affect the health of the community. The THQ values for $\mathrm{Cr}, \mathrm{Cu}, \mathrm{As}$ and $\mathrm{Pb}$ from consumption of $O$. niloticus from both sites were higher than those from consumption of $C$. gariepinus suggesting that the consumption of $O$. niloticus is potentially more risky than the consumption of $C$. 
gariepinus with respect to toxicities from these metals. On the other hand, the THQ values for Fe, Zn, Se and $\mathrm{Hg}$ from consumption of $C$. gariepinus from both sites were higher than those from consumption of $O$. niloticus implying that the consumption of $C$. gariepinus is potentially more risky than the consumption of $O$. niloticus with respect to the toxicities of these metals. The THQ values for Co and $\mathrm{Ni}$ from consumption of $C$. gariepinus and $O$. niloticus from both sites were equal, implying that the consumption of both fish species is just as potentially risky with respect to $\mathrm{Co}$ and $\mathrm{Ni}$ toxicities.

Hazard Index (HI): The HI values from the consumption of the two fish species, one to seven times a week, are shown in Table 3. The HI values through consumption of $C$. gariepinus from Lake Hawassa and Boicha stream ranged from 0.369 to 2.604 and 0.501 to 3.524 , respectively while those through consumption of $O$. niloticus were in the ranges of 0.284 to 1.994 and 0.425 to 2.984 for Lake Hawassa and Boicha stream, respectively. The HI values through consumption of $C$. gariepinus for three or more days a week, from Lake Hawassa, and two or more days a week from Boicha stream were greater than unity. This suggests the presence of a potential non-carcinogenic health risk from ingestion of all the heavy metals considered under this study collectively through consumption of the fish at aforementioned exposure levels from each site. The HI values through consumption of $O$. niloticus were similar to those mentioned above for $C$. gariepinus except that the exposure levels were three or more days a week for Boicha stream, and five or more days a week for Lake Hawassa. These results show that there is a higher potential non-carcinogenic health risks from the consumption of the two fish species from Boicha stream compared to consumption of the same fish species from Lake Hawassa. This might be due to effluents that the stream receives directly from the industries. Families of fishers and fish vendors around the study areas consume fish nearly every day; therefore, they are more vulnerable to heavy metal toxicity.

Table 3. Target Hazard Quotient (THQ) and Hazard Index (HI) of heavy metals from consumption of C. gariepinus and O. niloticus from Lake Hawassa and Boicha stream at different levels (days per week) of exposure.

\begin{tabular}{|c|c|c|c|c|c|c|c|c|c|c|c|c|c|}
\hline \multirow[b]{2}{*}{ Fish } & \multirow[b]{2}{*}{ Site } & \multirow{2}{*}{$\begin{array}{l}\text { Level of } \\
\text { Exposure } \\
(\mathrm{d} / \mathrm{w})\end{array}$} & \multicolumn{10}{|c|}{ Target Hazard Quotient (THQ) } & \multirow{2}{*}{$\begin{array}{l}\text { Hazard } \\
\text { Index } \\
(\mathrm{HI})\end{array}$} \\
\hline & & & $\mathrm{Cr}$ & $\mathrm{Fe}$ & $\mathrm{Co}$ & $\mathrm{Ni}$ & $\mathrm{Cu}$ & $\mathrm{Zn}$ & As & $\mathrm{Se}$ & $\mathrm{Hg}$ & $\mathrm{Pb}$ & \\
\hline \multirow{9}{*}{$\begin{array}{l}\text { Clarias } \\
\text { gariepinus }\end{array}$} & \multirow[t]{4}{*}{ A } & 1 & 0.002 & 0.001 & 0.000 & 0.000 & 0.001 & 0.007 & 0.028 & 0.036 & 0.293 & 0.001 & 0.369 \\
\hline & & 2 & 0.005 & 0.003 & 0.000 & 0.001 & 0.003 & 0.013 & 0.056 & 0.071 & 0.586 & 0.003 & 0.741 \\
\hline & & 3 & 0.007 & 0.004 & 0.001 & 0.001 & 0.004 & 0.020 & 0.084 & 0.107 & 0.880 & 0.004 & 1.112 \\
\hline & & 5 & 0.011 & 0.007 & 0.001 & 0.002 & 0.007 & 0.032 & 0.140 & 0.178 & 1.466 & 0.007 & 1.851 \\
\hline & \multirow[t]{5}{*}{ B } & 1 & 0.002 & 0.003 & 0.000 & 0.000 & 0.002 & 0.007 & 0.052 & 0.045 & 0.389 & 0.001 & 0.501 \\
\hline & & 2 & 0.005 & 0.007 & 0.000 & 0.001 & 0.004 & 0.013 & 0.103 & 0.089 & 0.778 & 0.003 & 1.003 \\
\hline & & 3 & 0.007 & 0.010 & 0.000 & 0.001 & 0.006 & 0.020 & 0.155 & 0.134 & 1.167 & 0.004 & 1.505 \\
\hline & & 5 & 0.012 & 0.017 & 0.000 & 0.002 & 0.010 & 0.032 & 0.258 & 0.223 & 1.945 & 0.007 & 2.507 \\
\hline & & 7 & 0.017 & 0.023 & 0.000 & 0.003 & 0.014 & 0.050 & 0.362 & 0.314 & 2.730 & 0.010 & 3.524 \\
\hline \multirow{9}{*}{$\begin{array}{l}\text { Oreochmis } \\
\text { niloticus }\end{array}$} & \multirow[t]{4}{*}{ A } & 1 & 0.004 & 0.001 & 0.000 & 0.000 & 0.002 & 0.005 & 0.086 & 0.023 & 0.160 & 0.003 & 0.284 \\
\hline & & 2 & 0.008 & 0.002 & 0.000 & 0.001 & 0.004 & 0.010 & 0.171 & 0.046 & 0.320 & 0.007 & 0.569 \\
\hline & & 3 & 0.012 & 0.004 & 0.000 & 0.001 & 0.006 & 0.014 & 0.256 & 0.070 & 0.480 & 0.010 & 0.853 \\
\hline & & 7 & 0.027 & 0.009 & 0.000 & 0.003 & 0.014 & 0.033 & 0.600 & 0.162 & 1.122 & 0.024 & 1.994 \\
\hline & \multirow[t]{5}{*}{ B } & 1 & 0.004 & 0.002 & 0.000 & 0.000 & 0.003 & 0.006 & 0.094 & 0.024 & 0.287 & 0.004 & 0.425 \\
\hline & & 2 & 0.011 & 0.003 & 0.000 & 0.001 & 0.006 & 0.011 & 0.189 & 0.049 & 0.574 & 0.007 & 0.851 \\
\hline & & 3 & 0.016 & 0.004 & 0.001 & 0.001 & 0.009 & 0.017 & 0.283 & 0.073 & 0.862 & 0.011 & 1.276 \\
\hline & & 5 & 0.027 & 0.007 & 0.001 & 0.001 & 0.014 & 0.028 & 0.472 & 0.122 & 1.436 & 0.018 & 2.125 \\
\hline & & 7 & 0.037 & 0.010 & 0.001 & 0.002 & 0.020 & 0.039 & 0.662 & 0.172 & 2.016 & 0.026 & 2.984 \\
\hline
\end{tabular}

Values in bold $(>1)$ indicate potential non-carcinogenic health risk for humans. $A=$ Lake Hawassa; $\mathrm{B}=\mathrm{Boicha}$ stream

Target Carcinogenic Risks (TCRs): The TCR from exposure to $\mathrm{Cr}, \mathrm{Ni}, \mathrm{As}$ and $\mathrm{Pb}$ due to consumption of $C$. gariepinus and $O$. niloticus from the two sampling sites, for one to seven days a week, are presented in Table 4. The highest TCR value for exposure of seven days a week obtained in this study was 8.82E-04 (for As) through consumption of $C$. gariepinus from Boicha stream, while the lowest was 1.02E-08 (for Pb) through consumption of $O$. niloticus from Lake Hawassa. In the present study, the TCR values for $\mathrm{Cr}$,
$\mathrm{Ni}$ and $\mathrm{Pb}$ were below the acceptable range $\left(<10^{-6}-10^{-}\right.$ ${ }^{4}$ ) for all levels of exposure. This indicates that there is no potential carcinogenic health risk from ingestion of $\mathrm{Cr}, \mathrm{Ni}$ and $\mathrm{Pb}$ through the consumption of $C$. gariepinus and $O$. niloticus for all levels of exposure from both sampling sites. However, the TCR values for As were above the acceptable range $\left(>10^{-6}-10^{-4}\right)$ for consumption of $C$. gariepinus every day from Lake Hawassa and five or more days per week from Boicha stream. Similarly, the TCR values for As from 
consumption of $O$. niloticus from both sites were above the acceptable range for exposure of three or more days a week. Therefore, it can be inferred that there is a potential carcinogenic health risk from ingestion of As through the consumption of both fish species from both sampling sites for the abovementioned exposure levels. It has been reported that long-term exposure of humans to As may cause cancers of the bladder, lung, kidney, and liver (Gbaruko et al., 2010).

Table 4 Target cancer risk (TCR) of heavy metals due to consumption of C. gariepinus and O. niloticus from Lake Hawassa and Boicha stream at different levels (days per week) of exposure.

\begin{tabular}{|c|c|c|c|c|c|c|}
\hline \multirow[t]{2}{*}{ Fish species } & \multirow[t]{2}{*}{ Site } & \multirow{2}{*}{$\begin{array}{l}\text { Level of } \\
\text { exposure }(\mathrm{d} / \mathrm{w})\end{array}$} & \multicolumn{4}{|c|}{ Target cancer risk (TCR) } \\
\hline & & & $\mathrm{Cr}$ & $\mathrm{Ni}$ & As & $\mathrm{Pb}$ \\
\hline Clarias & A & 1 & $3.38 \mathrm{E}-06$ & $1.42 \mathrm{E}-05$ & $1.26 \mathrm{E}-05$ & $3.85 \mathrm{E}-08$ \\
\hline \multirow[t]{9}{*}{ gariepinus } & & 2 & $6.75 \mathrm{E}-06$ & $2.85 \mathrm{E}-05$ & $2.51 \mathrm{E}-05$ & $7.70 \mathrm{E}-08$ \\
\hline & & 3 & $1.01 \mathrm{E}-05$ & 4.27E-05 & 3.77E-05 & $1.16 \mathrm{E}-07$ \\
\hline & & 5 & $1.69 \mathrm{E}-05$ & 7.12E-05 & $6.28 \mathrm{E}-05$ & $1.93 \mathrm{E}-07$ \\
\hline & & 7 & $2.37 \mathrm{E}-05$ & $1.0 \mathrm{E}-04$ & 1.63E-04* & $2.70 \mathrm{E}-07$ \\
\hline & B & 1 & $3.59 \mathrm{E}-06$ & $1.21 \mathrm{E}-05$ & 2.32E-05 & 4.14E-08 \\
\hline & & 2 & 7.18E-06 & $2.41 \mathrm{E}-05$ & 4.64E-05 & 8.28E-08 \\
\hline & & 3 & $1.08 \mathrm{E}-05$ & $3.62 \mathrm{E}-05$ & $6.96 \mathrm{E}-05$ & $1.24 \mathrm{E}-07$ \\
\hline & & 5 & $1.80 \mathrm{E}-05$ & $6.03 \mathrm{E}-05$ & $1.16 \mathrm{E}-04 \%$ & 2.07E-07 \\
\hline & & 7 & $2.52 \mathrm{E}-05$ & $8.47 \mathrm{E}-05$ & 8.82E-04\% & 2.91E-07 \\
\hline Oreochromis & A & 1 & $5.77 \mathrm{E}-06$ & $1.29 \mathrm{E}-05$ & $3.85 \mathrm{E}-05$ & $1.02 \mathrm{E}-08$ \\
\hline \multirow[t]{9}{*}{ niloticus } & & 2 & $1.15 \mathrm{E}-05$ & 2.59E-05 & 7.69E-05 & $2.03 \mathrm{E}-08$ \\
\hline & & 3 & $1.73 \mathrm{E}-05$ & $3.88 \mathrm{E}-05$ & $1.15 \mathrm{E}-04 *$ & $3.05 \mathrm{E}-08$ \\
\hline & & 5 & $2.88 \mathrm{E}-05$ & $6.47 \mathrm{E}-05$ & 1.92E-04* & $5.09 \mathrm{E}-08$ \\
\hline & & 7 & $4.05 \mathrm{E}-05$ & $9.08 \mathrm{E}-05$ & $2.70 \mathrm{E}-04 \%$ & $1.02 \mathrm{E}-08$ \\
\hline & B & 1 & 7.95E-06 & $7.85 \mathrm{E}-06$ & $4.22 \mathrm{E}-05$ & $1.09 \mathrm{E}-08$ \\
\hline & & 2 & $1.59 \mathrm{E}-05$ & $1.57 \mathrm{E}-05$ & $8.49 \mathrm{E}-05$ & $2.18 \mathrm{E}-08$ \\
\hline & & 3 & 2.38E-05 & $2.35 \mathrm{E}-05$ & 1.27E-04* & $3.27 \mathrm{E}-08$ \\
\hline & & 5 & 3.97E-05 & $3.92 \mathrm{E}-05$ & 2.12E-04* & $5.45 \mathrm{E}-08$ \\
\hline & & 7 & $5.58 \mathrm{E}-05$ & $5.51 \mathrm{E}-05$ & $2.98 \mathrm{E}-04 \%$ & $7.65 \mathrm{E}-08$ \\
\hline
\end{tabular}

Conclusions: From the findings of this study, it is concluded that consumption of the two fish species from both water bodies could be unsafe with respect to toxicities of $\mathrm{Cr}, \mathrm{Cu}, \mathrm{Hg}$ and As. This puts the neighboring communities into health risk and hence calls for regular monitoring. The study also presents relevant information on ecological health of water bodies in a developing country, where industries have not flourished, and provides basic data for comparative studies with highly industrialized parts of the world.

Acknowledgements: This study was financed by the Institutional Collaboration Program between the Norwegian University of Life Sciences (NMBU) and Hawassa University, supported by the Royal Norwegian Embassy in Addis Ababa. We thank Pia Frostad and Solfrid Lohne, from Norwegian University of Life sciences, for their help in the laboratory analyses of the samples.

\section{REFERENCES}

Abayneh, A; Taddese, W; Chandravanshi, BS (2003). Trace Metals in selected fish species from Lakes Awassa and Ziway, Ethiopia. Momona. Ethiop. J. Sci. 26(2):103-114

Abdulali, T; Shuhaimi-Othman, M; Ahmad, AK (2013).Assessment of heavy metals in tilapia fish
(Oreochromisniloticus) from the Langat River and Engineering Lake in Bangi, Malaysia, and evaluation of the health risk from tilapia consumption. Ecotox. Environ. Safe. 93:45-51

Alam, MG; Allinson, G; Stagnitti, F; Tanaka, A; westbrook, M (2010). Arsenic contamination in Bangladesh groundwater: A major environmental and social disaster. Int. J. Environ. Health Res. $12(3): 235-253$

Amanial, H; Adugna, A (2016). Accumulation and distribution of some selected heavy metals in both water and some vital tissues of two fish species (Oreochromis niloticus and Clarias gariepinus) from Lake Chamo Ethiopia. Int. J. Fish. Aquat. Stud. 4(5): 06-12

Alemayehu, A; Tamiru, C (2019). Socio-economic importance of Fish production and consumption status in Ethiopia: A review. Int. J. Fish. Aquat. Stud. 7 (4):206-211

Berehanu, B; Lemma, B; Tekle-Giorgis, Y (2015). Chemical Composition of Industrial Effluents and Their Effect on the Survival of Fish and Eutrophication of Lake Hawassa, Southern Ethiopia. J. Environ. 6:792-803

Dessie, T; Dereje, L; Gizachew, T (2019). Determination 
of Heavy metals in Tilapia (Oreochromis niloticus) and water samples from Lake Hayq, South Wollo, Ethiopia. Int J Chem Mater Res. 7(1): 10-19

Ermias, D; Elias, D; Ole, ME (2014). Level of mercury in fish from the Ethiopian Rift Valley Lakes: Its implications in dietary exposure. Ethiop. J. Biol. Sci. 13(1):25-35

FAO/WHO (1989). National Research Council Recommended Dietary 626 Allowances (10th ed). National Academy Press. Washington, DC. USA.

FAO/WHO (2011). Joint FAO/WHO food standards programme codex committee on contaminants in foods, fifth. session pp 64-89.The Netherlands

FAO (2014). Fisheries in the ESA-IO Region: Profile and Trends: Country Review SmartFishProgramme/Ethiopia.

Gbaruko, BC; Ana, G; Nwachukwu, JK (2010). Ecotoxicology of arsenic in the hydrosphere: Implications for public health. Afr. J. Biotechnol. 7(25): 4737-4742

Gezahegn, A (2017). Long-term climate data description in Ethiopia. Data in Brief. 14: 371-392.

Gure, A; Kedir, K; Abduro, F (2019). Heavy Metal ConcentrationsinFish Tissues from Gilgel Gibe (I) Hydroelectric Dam Reservoir, Ethiopia. Appl. Sci. Environ. Manage. 23 (8):1411-1416.

Honda, S; Hylander, L; Sakamoto, M (2006). Recent advances in evaluation of health effects on mercury with special reference to methylmercury: a mini review. Environ Health Prev. 11 (4): 171-176.

Kawser, A; Mohammad, AB; Goutam, K; Saiful, I; Monirul, I; Muzammel, H (2016). Human health risks from heavy metals in fish of Buriganga River, Bangladesh. SpringerPlus.5:1697.

Larissa, D; Mesfin, M; Elias, D; Carlos, EV; Sven, S (2013). Assessment of heavy metals in water samples and tissues of edible fish species from Awassa and Koka Rift Valley Lakes, Ethiopia. Environ. Monit. Assess. 185:3117-3131.

Mahboob, S; Al-Balawi, FHA; Al-Misned, F; AlQuraishy, S; Ahmad, Z (2014). Tissue Metal Distribution and Risk Assessment for Important Fish Species from Saudi Arabia. B Environ Contam Tox. 92:61-66.

Rosseland, BO; Massabuau, JC; Grimalt, J; Lackner, RH; Raddum, RG; Rognerud, S; Vives, I (2001). Fish ecotoxicology, The EMERGE fish sampling manual for live fish. The EMERGE Project (European Mountain Lake Ecosystems: Regionalisation, diagnostic and socio-economic evaluation) (http://www.mountainlakes.org/emerge/methods/29.pdfl).

Tariku, M; Reidar, B; Bjørn, OR (2011). Mercury concentrations are low in commercial fish species of Lake Ziway, Ethiopia, but stable isotope data indicated biomagnifications. Ecotox. Environ. Safe.74:953-959.

USEPA (1989). Risk Assessment Guidance for Superfund. Human Health Evaluation Manual Part A, Interim Final, Vol. I.EPA/540/1-89/002.

USEPA (2003). Integrated Risk Information System (IRIS).Chemical Assessment Summary.

USEPA (2010). International Agency for Research on Cancer. IARC monographs on the evaluation of carcinogenic risk to human. Volume 100C. Lyon.

USEPA (2012). EPA Region III Risk-Based Concentration (RBC) Table 2008 Region III, 1650 Arch Street, Philadelphia, Pennsylvania 19103

USEPA (2019). USEPA Regional Screening Level (RSL) Summary Table.

WHO (2007). Health risks of heavy metals from longrange transboundary air pollution. Regional Office for Europe. Germany.

WHO (2012). WHO Country Cooperation Strategy 20122015: Ethiopia. Regional Office for Africa.

WHO (2015).World Health Statistics. 1211 Geneva 27, Switzerland.

Yared, B; Yoshinori, I; Aksorn, S; Kensuke, PW; Shouta, $\mathrm{N}$; Mayumi, I (2013). Concentrations and human health risk assessment of organochlorine pesticides inedible fish species from a Rift Valley lake-Lake Ziway, Ethiopia. Ecotox. Environ. Safe.106:95-101.

Yonas, A; Menberu, B; Tenalem, A; Clement, A; Assegid, C; Mulugeta, D (2018). Morphometric Change Detection of Lake Hawassa in the Ethiopian Rift Valley. Water. 10:625.

Zinabu, GM; Zerihun, D (2002). The chemical composition of the effluent from Awassa textile factory and its effect on aquatic biota. SINET: Ethiop. J. Sci. 25(2):263-274.

Zinabu, GM; Pearce, JG; Ahlgren, I (2004). Toxic metals and related trace elements in some Ethiopian hot springs. Ethiop. J. Biol. Sci. 3 (1):69-80. 